\title{
Effects of Thought Stopping Therapy on Anxiety in the Elderly Facing the Covid 19 Pandemic in Elderly Home
}

\author{
Niken Yuniar Sari ${ }^{1}$, Budi \\ Antoro $^{1}$, Maria Septijantini Alie ${ }^{2}$ \\ ${ }^{1}$ Nursing Program, Health Faculty, \\ Universitas Mitra Indonesia \\ ${ }^{2}$ Business Faculty, Universitas \\ Mitra Indonesia \\ Email: \\ nikenyuniar@umitra.ac.id
}

Received : October 5, 2020

Accepted : November 27, 2020

Published : November 30, 2020

\begin{abstract}
Thought stopping is a therapy that can help stop disruptive thoughts from changing the thought process. This study aims to determaine the influence of thought stopping therapy on anxiety in the elderly facing the Covid 19 Pandemic in Elderly home. This study used quasi eksperimental design with pre-post test with control group. Responden were 70 people that devided into two group. They were 35 as intervention group that received thought stopping and 35 as control group that received nursing therapy of anxiety. Result showed anxiety in the intervention group decreased from moderate anxiety to mild anxiety and control group decreased still in the moderate anxiety. Thought stopping decreased physiologic, cognitive, behaviour and emotional responses of anxiety significantly ( $\mathrm{p}$ value $<0,05$ ). thought stopping therapy was recommended as therapy to solve the anxiety at home elderly and community.
\end{abstract}

Keywords: Anxiety, Elderly, Thought Stopping

Copyright (C) 2020 IIK STRADA Indonesia All right reserved.

\section{cc) (†) (9)}

This is an open-acces article distributed under the terms of the Creative Commons Attribution-ShareAlike 4.0 International License.

\section{INTRODUCTION}

Coronavirus disease (COVID 19) is an infectious disease caused by the corona virus. Most people infected with Covid 19 will experience mild to moderate respiratory disease and recover without requiring special treatment. Elderly and patients with medical problems such as cardiovascular disease, diabetes, chronic respiratory disease and cancer are more likely to develop serious illnesses. (WHO, 2020).

On December 31, 2019, the WHO China Country Office reported a case of pneumonia of unknown etiology in Wuhan, Hubei Province, China. On January 7, 2020, China identified pneumonia of unknown etiology as a new type of corona virus (corona virus disease, COVID-19). On March 2, 2020, Indonesia reported 2 confirmed cases of COVID-19. As of July 26, 2020, Indonesia has reported 98,778 confirmed cases of COVID-19 where the mortality ratio is $4.8 \%$ (4,781 people), Patient under surveillance. under treatment is $37.8 \%$ (37,342 people) and patients recovered $57.4 \%$ (56,655 people).

WHO (2020) the emergence of a pandemic has caused stress on various levels of society. Especially the elderly in isolation and cognitive decline or dementia may become more anxious, angry, stressed, restless and withdrawn during an outbreak. According to research (Yip et al., 2010) there is a relationship between pandemics and increased symptoms of stress, anxiety, worry, posttraumatic stress and suicide.

Pradana (2020), the elderly are the group most at risk of transmitting and contracting the virus. The elderly are considered to be at high risk for COVID 19 because a weak immune system and the presence of comorbid chronic diseases cause a higher risk of death (Meng et all, 2020). Death data 
from the Oxford COVID-19 Evidence Service (25/3/20) shows 3.6\% are 60 years old and $14.8 \%$ are 70 years old. A number of studies related to the pandemic have shown a negative impact on the mental health of sufferers. A study by (Huang \& Zhao, 2020) shows positive results that people in China experience generalized anxiety disorders and depressive symptoms as well as poor sleep quality.

Anxiety is an unclear and pervasive feeling of fear associated with feelings of uncertainty and helplessness. This emotional state does not have a specific object, is experienced subjectively and communicated interpersonal. When feeling anxious, the individual feels uncomfortable or has a feeling that a catastrophe will be hit even though he does not understand why these threatening emotions occur (Videbeck, 2011). This shows that the anxiety experienced by individuals is subjective and not the same as one another.

Anxiety consists of four levels, namely mild, moderate, severe to panic (Videbeck, 2011). Each level causes changes in the perceptual, physiological and emotional fields of the individual. A person with mild anxiety is still broad and alert, whereas an individual with anxiety is focusing only on the thoughts that are his attention, but the individual can still do something under the direction of others. Meanwhile, severe anxiety and panic, the field of perception is very narrow, losing control and even being unable to do anything even with the directions of others. Nanda (2012) Anxiety is defined as feeling unclear caused by discomfort or fear accompanied by autonomic nervous responses (sources are often unclear), feelings of anxiety are caused by anticipating danger. If the anxiety condition is allowed to become chronic and cause mal adaptive behavior, then the anxiety will no longer function as a warning sign of danger, but has become a sign of disturbance which is then referred to as anxiety.

One of individual therapy that can be used to reduce anxiety is thought stopping therapy. Thought stopping is a therapeutic process that can help stop distracting thoughts. Thought stopping therapy is part of behavioral therapy used to help change thinking processes. Habits of thinking can shape behavioral changes, with one automatic thought alone giving clues to other thoughts that are threatening. A self-taught stopping technique that can be used whenever an individual wants to remove disturbing or negative thoughts and unwanted thoughts from consciousness (Nasution, 2011). The choice of this therapy is based on the discovery of cognitive data on disturbing thoughts that make the elderly become anxious (Stuart \& Laraia, 2005) explaining that thought cessation therapy is a therapy that can help someone stop disturbing thoughts.

\section{MATERIALS AND METHODS}

This research uses a "Quasi experimental with control group of pre-and-post-test" design. The research was conducted at Elderly home on July, 2020. The research population is elderly. The sampling technique is purposive sampling which the respondents were chosen based on the inclusion criteria as follows: elderly who can still hear and who are able to communicate. This study used a Generalized Anxiety Disorder (GAD) -7 questionnaire. The data was analyzed by using univariate and bivariate analysis with dependent t-test, and independent t-test Measure by computer. The Authors this research have passed the validity and competency test by the experts.

\section{RESULTS}

The average age of the elderly is almost 69 years old. The youngest was 60 years old, and the oldest 78 years old. Most of the elderly are male, namely 24 people $(68.8 \%)$. The majority of the education level of the elderly is not in school as many as 22 people $(62.9 \%)$, while the majority of the work of the elderly are laborers totaling 22 people (62.9\%). The average length of stay in the elderly home for the elderly is 4 years with the longest data being 13 years.

Table 1. Anxiety in the Elderly at UPTD Tresna Werdha Elderly Home Natar South Lampung July 2020 (N=70)

\begin{tabular}{lccccccc}
\hline Variable & Group & N & Mean & Median & Min-Max & SD & 95\%CI \\
& & & & & & & \\
\hline Anxiety & Intervention & 35 & 12.43 & 13.00 & $10-14$ & 1.335 & $11.97-12.89$ \\
\cline { 2 - 8 }
\end{tabular}




$\begin{array}{lllllll}\text { Control } & 35 & 12.31 & 13.00 & 10-14 & 1.207 & 11.90-12.35\end{array}$

Table 1. showed that the average anxiety in the elderly before being given thought stopping therapy was 12.43 (moderate) in the treatment group and 12.31 (moderate) in the control group. with the lowest score is 10 and the highest is 14 (moderate). The results of the 95\% interval estimate indicate that the mean anxiety in the treatment group is 11.97 to 12.89 .

Table 2. Differences of Anxiety in the Elderly Pre test and Post test at UPTD Tresna Werdha Elderly Home Natar South Lampung July 2020 (N=35)

\begin{tabular}{cccccc}
\hline Variable & Group & $\mathbf{N}$ & $\begin{array}{c}\text { Mean } \\
\text { Pre Test }\end{array}$ & $\begin{array}{c}\text { Mean } \\
\text { Post Test }\end{array}$ & \multirow{2}{*}{ P value } \\
\cline { 1 - 5 } Anxiety & Intervention & 35 & 12.43 & 7.77 & \multirow{2}{*}{0.000} \\
\cline { 2 - 5 } & Control & 35 & 12.31 & 11.46 & \\
\cline { 2 - 5 } & Total & 70 & 12.37 & 9.61 & \\
\hline
\end{tabular}

According to Table 2 the mean anxiety in elderly after given thought stopping therapy in the treatment group (7.77) was smaller than the control group $(11,46)$. The results of statistical tests showed that there was a significant difference between elderly anxiety in the treatment and control groups (p-value 0.000).

\section{DISCUSSION}

The results showed that the average anxiety in the treatment group given thought stopping therapy before treatment was 12.43 (moderate) and after treatment decreased to 7.77 (mild). There was a significant decrease in elderly anxiety before and after treatment in the group given thought stopping therapy (P-value <0.05). Meanwhile, in the control group that was not given thought stopping therapy, the average anxiety level in the elderly was still at a moderate level of anxiety, namely 11.46. It can be concluded that thought stopping was able to significantly reduce anxiety scores compared to the group that was only given nurse nursing action.

The anxiety experienced by the elderly is at a moderate level, based on the observations of researchers during the research process showing that the physiological signs displayed by respondents are tension and feelings of discomfort. Fortinash and Worret (2004) anxiety can be shown normally, increasing and decreasing fight or flight. This is explained by Videbeck (2011) who explains that the response of the autonomic nervous system to anxiety causes involuntary activity in the body which is included in self-defense. Sympathetic nerve fibers activate vital signs at any alarm to prepare the body's defenses. The adrenal glands release adrenaline (epinephrine), which causes the body to take in more oxygen, dilates the pupil and increases arterial pressure and heart frequency while constricting peripheral blood vessels and blood from the gastrointestinal and reproductive systems and increasing glycogenolysis to free glucose to support the heart, muscles and muscles. central nerve system. When the danger has ended, the parasympathetic nerve fibers reverse this process and return the body back to normal until the next threat sign reactivates the sympathetic responses.

Thought Stopping is a self-taught stopping technique that can be used whenever an individual wants to remove disturbing thoughts and unwanted thoughts from consciousness (Townsend, 2009). The disturbing thoughts experienced by the elderly are a threat of death for the elderly that cause feelings of fear, worry and anxiety. The elderly are increasingly reluctant to meet other people, and are suspicious of other people that can infect other people and transmit the virus to themselves. After being given thought stopping therapy, the elderly are able to stop disturbing thoughts. This is in accordance with Stuart (2013) that thought stopping is a patient's thinking disorder that often has a snowball-like effect. Thoughts that start out as minor problems and have no effect can over time converge and important situations that can hardly be stopped. The mind-stopping technique is the best technique to use when distraction first arises.

Thought stopping therapy was carried out with 2 kinds of exercises, the first was that the respondents were taught to stop their thoughts on a regular basis, while the second with a varied count. Stopping thoughts with a varied count was carried out if the respondent was able to do a regular count of stopping thoughts. Stopping thoughts with a varied count in session 2 is intended to 
train respondents to get used to stopping disturbing thoughts as quickly as possible when disturbing thoughts arise. By using a varied count, respondents will be able to gradually accelerate the emergence of adaptive behavior in the form of stopping annoying thoughts. With this exercise, respondents will quickly adapt to their anxiety conditions, they no longer need a long time to stop disturbing thoughts. In the final stage, what is expected in this exercise is that the respondent is able to stop the thought quickly, as soon as a thought suddenly appears without having to concentrate and focus the mind to imagine disturbing thoughts mastering his mind as in the first exercise session.

Based on the results of the research and the above explanation, thought stopping therapy shows a decrease in the level of moderate to mild anxiety in the elderly in the face of the COVID 19 pandemic in a physiological response to experiencing feelings of uneasiness, disruption of sleep patterns, body condition easily tired and muscles feeling tense. Thought stopping therapy in the elderly with anxiety improves the elderly's ability to do interfering thoughts that cause anxiety by saying "Stop" physiologically giving commands to the brain, thereby affecting the activity of the neurotransmitter gamma aminobutyric acid (GABA), which is responsible for producing anxiety (Stuart, 2013). Gamma aminobutyric acid (GABA) is a neurotransmitter that acts as an inhibitor in the brain. In neurological studies it was stated that there was a decrease in GABA and benzodiazepine GABA receptors in clients with anxiety. The brain has special receptors against benzodiazepines that function to assist the regulatory system in anxiety (Townsend, 2010).

Townsend (2009) defines distracting thought stopping therapy as a mind-stopping technique performed by individuals if they want to stop or eliminate disturbing thoughts that are overpowering and unwanted thoughts. Elderly people who have difficulty focusing due to repetitive or maladaptive disturbing thoughts are very suitable for this therapy. Previous research has shown that thought stopping therapy can overcome anxiety in patients with physical illnesses (Supriatin et al 2010).

(Agustarika, 2009) in his research explained that the use of thought stopping therapy had a significant effect in reducing the anxiety of patients with physical disorders at the Sorong District Hospital. The results obtained in 43 patients as respondents showed a decrease in anxiety after thought stopping therapy when compared to respondents who did not receive thought stopping therapy. Research by Nasution (2011) shows that caregiver anxiety levels with children undergoing chemotherapy have decreased significantly after being given thought stopping therapy. The results of this study are also supported by the statement of Tang and DeRubies (Shives, 2005) explaining that thought stopping is an example of cognitive behavior psychotherapy that can be used to help patients change thought processes.

\section{CONCLUSION}

This study shows that Thought Stopping Therapy affects the anxiety of elderly facing the COVID 19 pandemic. Thought stopping is recommended for the treatment of anxiety in elderly homes and communities because thought stopping therapy is a therapy help decrease level of anxiety caused by disturbing thoughts that make a person unable to focus. This ability is needed to change the maladaptive behavior caused by anxiety so that it becomes adaptive behavior.

\section{ACKNOWLEDGMENTS}

The author is thankful to respondents for their valuable information and their awareness to participate in this research.

\section{CONFLICTS OF INTEREST}

The author declares that they have no conflict of interest

\section{REFERENCES}

Agustarika, B. (2009). Pengaruh Terapi Thought Stopping terhadap Ansietas Klien dengan Gangguan Fisik di RSUD Kabuaten Sorong. 1-112.

Covid-19. (2020). Data Covid -19 Indonesia. Retrieved from: https://covid19.kemkes.go.id/situasiinfeksi-emerging/info-corona-virus/situasi-terkini-perkembangan-coronavirus-disease-covid19-25-juli-2020/\#.XzSI0NRS-1s

Fortinash, K.M \& Worret, P.A.H (2004). Psychiatric mental health nursing. ( $3^{\text {th }}$ ed). St.louis: Mosby. 
Huang, Y., \& Zhao, N. (2020). Generalized anxiety disorder, depressive symptoms and sleep quality during COVID-19 outbreak in China: a web-based cross-sectional survey. Psychiatry Research, 288(April): 112954. https://doi.org/10.1016/j.psychres.2020.112954

Meng, H., Xu, Y., Dai, J., Zhang, Y., Liu, B., \& Yang, H. (2020). Analyze the psychological impact of COVID-19 among the elderly population in China and make corresponding suggestions. Psychiatry research,289, 112983. Advance online publication. https://doi.org/10.1016/j.psychres.2020.112983.

Nanda International., \& Herdman, T. H. (2012). Nanda International Nursing diagnoses: Definitions and classification 2012-14. Chichester, U.K; Ames, Iowa: Wiley-Blackwell.

Nasution (2011). "Perngaruh Thought Stopping Terhadap Tingkat Kecemasan Keluarga Dengan Anak Usia Sekolah Yang Menjalani Kemoterapi di RSUPN Dr Cipto Mangunkusumo”. Dalam darf modul terapi, Spesialis keperawatan jiwa, Jakarta: FIK UI. Not published.

Pradana, A. A., \& Casman, C. (2020). Pengaruh Kebijakan Social Distancing pada Wabah COVID-19 terhadap Kelompok Rentan di Indonesia. Jurnal Kebijakan Kesehatan Indonesia: JKKI, 9(2), 61-67.

Shives. (2005). Basic concept of Psychiatric-mental health nursing. Lippimcott: William \& Wilkins.

Supriatin, L. Keliat, B.A, Nuraeni T, \& Susanti, H. (2010). Pengaruh Terapi Penghentian Pikiran dan Relaksasi Otot Progresif terhadap Ansietas Pada Klien Gangguan Fisik di RSUD dr Soedono Madiun. Tesis: Fakultas Ilmu Keperawatan Universitas Indonesia.

Stuart \& Laraia (2005). Principles and practice of Psychiatric nursing. St. Louis: Mosby

Stuart, G.W. (2013). Principles and Practice of Psychiatric Nursing $\left(10^{\text {th }} \mathrm{ed}\right)$. St. Louis, Missouri: Mosby Elsevier.

Townsend, C.M (2009) Psychiatric Mental Health Nursing. 6nd Editin. Philadelphia: F.A Davis Company.

Townsend, M.C (2010). Buku Saku Diagnosis Keperawatan Psikiatri Rencana Asuhan \& Medikasi Psikotropik.Edisi 5. Jakarta: Penebit Buku Kedokteran EGC.

WHO (2020). Mental health and psychosocial considerations during the COVID 19 outbreak.

Yip, P. S. F., Cheung, Y. T., Chau, P. H., \& Law, Y. W. (2010). The impact of epidemic outbreak: The case of severe acute respiratory syndrome (SARS) and suicide among older adults in Hong Kong. Crisis, 31(2), 86-92. 